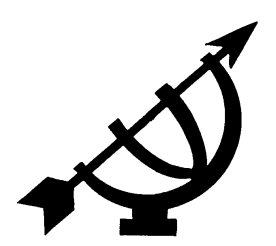

\title{
Die proses van waardeverheldering in die Suid-Afrikaanse onderwysopset beoordeel vanuit reformatoriese perspektief
}

\author{
J.L. van der Walt
}

Fakulteit Opvoedingswetenskappe

Potchefstroomse Universiteit vir $\mathrm{CHO}$

POTCHEFSTROOM

E-pos: jlvdwalt@intekom.co.za

\begin{abstract}
The process of values clarification in South African education from a reformational perspective

Values clarification has been playing a key role in education in South African schools since 1996. In this article a discussion of this approach in education leads to a search for answers to questions such as "Whose values are clarified?" and "When/Where does the process of clarification end?" Answers to questions such as these and an outline of guidelines sprouting from a reformational foundational framework lead the author to conclude that values-clarification education has only limited value: it merely clarifies the public moral code endorsed by the (education) authorities. Other value systems, including a reformational one, should also be involved in the process for it to become more educationally relevant.
\end{abstract}

Opsomming

Die proses van waardeverheldering in die Suid-Afrikaanse onderwysopset beoordeel vanuit Reformatoriese perspektief

Waardeverheldering speel sedert 1996 'n sleutelrol in die Suid-Afrikaanse onderwys. In dié artikel word gesoek na antwoorde op vrae soos: "Wie se waardes word verhelder?" en "Wanneer/Waar eindig die proses van waardeverheldering?" Antwoorde op hierdie vrae en die riglyne voortvloeiend uit 'n reformatoriese denkraamwerk lei tot die konklusie dat die waardeverhelderingsproses soos dit tans daar uitsien, slegs beperkte waarde het: dit lei eintlik maar net tot die verheldering van die waardes opgeneem in die openbare morele kode soos onderskryf deur die huidige (onderwys-)owerhede. Ander waardesisteme, insluitend die reformatoriese, behoort ook in die proses betrek te word ten einde te verseker dat die proses opvoedkundig relevant bly. 


\section{Inleiding, probleemstelling en ondersoekmetode}

'n Beleid van waardeverheldering word sedert 1996 in die SuidAfrikaanse onderwysstelsel gevolg. In aansluiting by die ondersoek van De Klerk (2000) word in hierdie artikel met die volgende probleem geworstel: Wat is die waarde van hierdie waardeverhelderingsproses? Die soeke na 'n antwoord op hierdie vraag moet plaasvind teen die agtergrond van die een of ander normatiewe raamwerk. In hierdie geval word 'n reformatoriese denkraamwerk gebruik. Die besinning verloop soos volg: ten eerste vind konseptuele verheldering plaas; daarna word beskryf hoe waardeverhelderende onderwys besig is om gestalte aan te neem in die Suid-Afrikaanse onderwysopset, en die bespreking word afgesluit met 'n slotsom oor die waarde van waardeverhelderende onderwys, soos dit tans daar uitsien. Die ondersoek word gelei en gerig deur die sentraal-teoretiese argument dat die proses van waardeverheldering in die onderwys slegs opvoedkundig en van waarde kan wees indien dit poog om, benewens die waardes opgeneem in die openbare morele kode van 'n land, ook die waardes opgesluit in die onderskeie spesifieke waardestelsels van onder meer die verskillende godsdienstige groeperinge in die land te verhelder.

\section{Konseptuele raamwerk}

Die volgende konsepte speel 'n sentrale rol in die hieropvolgende besinning:

\subsection{Waardes}

Elke menslike handeling word deur die een of ander beginsel-, norm- of waarderaamwerk gerig en bepaal. In teenstelling met 'n "modernistiese" (rasionalistiese) benadering, ingevolge waarvan onderwys gerig en bepaal word deur relatief vaste en onveranderlike beginsels, norme en denkpatrone (vgl. Middleton \& Walsh, 1995:18 e.v.), is daar tans 'n neiging tot 'n fundering van onderwysgebeure in "waardes". Gedurende die afgelope drie-vier dekades is daar ' $n$ voorkeur in die vakliteratuur vir "waardes" eerder as vir "norme" of "beginsels". Hierdie voorkeur is onder andere toe te skryf aan die invloed van die postmodernisme wat die klem plaas op dit wat vir die betrokke individu, gegewe die situasie op daardie oomblik, van waarde is. Middleton en Walsh (1995:35) tipeer die oorgang vanaf die relatiewe vastheid van beginseldenke na die relatiewe vloeibaarheid van waardedenke soos volg: "Renouncing the nostalgia for a total scheme of things because it is both unattainable and inherently violent is a characteristic postmodern theme". 
- Beginsels is dus relatief vaste uitgangs- of vertrekpunte gefundeer in die een of ander lewensvisie.

- Waardes is meer vloeiend en wisselend na gelang van omstandighede (soos verderaan verduidelik word).

- Norme hou met beginsels verband in die sin dat hulle beskou kan word as die maatstawwe aan die hand waarvan die toepassing van beginsels gemeet of beoordeel kan word.

Waardes kan wissel na gelang van die situasie, is altyd relatief tot die situasie en die heersende omstandighede. Hulle is ook in hoë mate gebonde aan dit wat die betrokke individu in die gegewe situasie as waardevol beskou. Waardes is dus gerelativeer aan die individu, en nie noodwendig "vas" gewortel in die een of ander lewensbeskouing of religieuse standpunt of beskouing nie. Tennekes (1992:53) vat die gedagtegang agter die hedendaagse huldiging van waardes soos volg saam:

Waarden - dat wil zeggen concepties omtrent de waarde en de zin van het menselijk bestaan en de dinge waar het in het leven om gaat vormen de basis zowel van het samenleven als van het beleid van een overheid die een verzorgingsstaat bestuurt. (Er) bestaat ... een geweldig waarden-relativisme. Waardeoordelen zijn verdacht, want subjectief en persoonlijk zo meent men. Waar het om gaat zijn de objectieve feiten en verder moeten mensen zelf maar weten welke waarden ze willen aanhangen. Het wordt ons voorgehouden dat we gedragscodes van de meest diverse aard hebben te respecteren of althans te tolereren. Waarden zijn ... een zaak van individuele voorkeuren, waarover mensen nu eenmaal met elkaar van mening verschillen.

Met die nadruk op waardes vervlugtig die basis waarop samelewingsverbande gebou word, naamlik 'n vorm van konsensus oor wat ten minste as sentrale waardes beskou behoort te word (Tennekes, 1992: 55). Dié siening strook met Humalda (1995:73) s'n. Laasgenoemde wys daarop dat die huidige postmoderne tyd erkenning gee aan die feit dat mense verskillend is, en dat dit onmoontlik is om alle mense "op één noemer te krijgen".

\subsection{Waardeverhelderende onderwys}

In die lig van die pluraliteit van waardes in 'n land soos Suid-Afrika, sê De Klerk (2000:342), en die feit dat jongmense in 'n gefragmenteerde samelewing soos dié gekonfronteer word met botsende en mededingende waardes, kan die waardeverhelderingsmodel moontlik uitkoms bied. Hierdie model kan uitkoms bied hoofsaaklik op grond van die volgende: 
- Daar is of hoef geen konsensus van waardes te wees nie.

- Morele voorskriftelikheid word vermy.

- Die enkeling word nie ondergeskik gestel aan die belange van enige groep nie.

Binne die waardeverhelderingsmodel val die nadruk hoofsaaklik op selfaktualisering, die verstaan van eie emosies en begrip van die waardevolle-vir-die-self. Ook is daar meer klem op die psigies gesonde selfaktualiserende persoon as op die moreel opgevoede persoon (De Klerk, 2000:343). Omdat waardes relatief vloeibaar en wisselend van aard is (Jeffrey, 1997:38), is dit nodig om voortdurend verheldering daarvan te doen. Deur gesprek met ander mense (die opvoeder en ander leerders) kom 'n mens dan tot helderheid oor die waardes wat jy as enkeling vir jouself aan bepaalde handelinge en standpunte wil heg. In waardeverhelderende onderwys geskied hierdie proses in die skole, met ander woorde tydens die onderrig-leersituasie (kyk ook 3 en verder hieronder).

\subsection{Reformatoriese denkraamwerk}

'n Reformatoriese denkraamwerk dui op 'n lewensbeskouing of verwysingsraamwerk gegrond op die Bybel as die geïnspireerde Woord van God. Die lewensbeskouing van die mens het te doen met die mees basiese vrae wat die mens oor die lewe en die menslike bestaan stel. Dit sluit antwoorde op die volgende vier (stelle) vrae in:

- Waar kom ons vandaan, en wie is ons?

- Wat het met die wêreld/die werklikheid gebeur en wat het alles skeefgeloop? Wat is die menslike dilemma?

- Wat kan ons doen om hierdie probleme/dilemma reg te stel?

- Hoe kan ons ons lewensvisie ten volle uitleef? Hoe kan die manier waarop ons die wêreld en die werklikheid sien, ons lei om die huidige stand van sake te verander? (Colson, 2001:xvii-xviii, 297; Middleton \& Walsh, 1995:19).

In die geval van 'n reformatoriese denkraamwerk word hierdie vrae vanuit 'n Bybelsgefundeerde standpunt beantwoord. Die eerste vraag het naamlik te doen met die skeppingsmotief, die tweede met die sondeval, die derde met herstel in Jesus Christus, en die vierde met die herstel van die kulturele omgewing waarin die mens hom of haar bevind.

\subsection{Die terme "neutraal" en "sekulêr"}

In die bespreking hierna word die terme "neutraal" en "sekulêr" meestal in verband met die openbare morele kode gebruik. Hierdie gebruik is 
ooreenkomstig die betekenisse uiteengesit in die Collins Concise Dictionary (1999). "Neutraal" beteken letterlik om nie kant te kies, byvoorbeeld in 'n dispuut nie, om onpartydig te wees. "Sekulêr" beteken "wêrelds", met ander woorde "not concerned with or related to religion", "having no particular religious affinities". As die openbare morele orde dus as "sekulêr" bestempel word, beteken dit nie bloot dat dit 'n neutrale of onpartydige karakter het nie, maar dat dit inderdaad wêrelds is, geen godsdienstige aard of karakter het of probeer hê nie.

\section{Waardeverheldering in die Suid-Afrikaanse onderwys- opset sedert 1996}

Op 6 Mei 2003 verduidelik Onderwysminister Kader Asmal die beleid van waardeverheldering wat tans in die Suid-Afrikaanse onderwysopset gevolg word. Volgens hom is dit die verklaarde uitgangspunt van die onderwysbewindhebbers dat leerders moet saamgesels oor watter waardes alle Suid-Afrikaners met mekaar eens behoort te wees, en wat hulle met mekaar moet deel. Dit moet gedoen word ten einde 'n gemeenskaplike nasionale identiteit te bou. Die doel van hierdie proses van waardeverheldering is dus nasiebou en die versterking van nasietrots. In hierdie gesprekke moet die nasionale simbole 'n sentrale rol speel. Volgens die Minister (Asmal, 2003) weerhou die onderwysowerhede hulself doelbewus daarvan om bepaalde waardes aan leerders voor te skryf en hulle sodoende te indoktrineer met 'n bepaalde waardesisteem (soos wat byvoorbeeld tydens die apartheidsbedeling die geval was).

Die Minister beskryf die proses van waardeverheldering in die onderwys ook in sy voorwoord tot die Manifesto on Values, Education and Democracy wat in 2001 deur die Onderwysministerie gepubliseer is. Daarin stel hy dat die departement 'n visie koester van 'n nasie wat homself uit die moeras van apartheid lig en waarin almal saamgevoeg word in verenigende strome van demokrasie en nasiebou (Asmal, 2001a:i). Die Manifesto vorm 'n breë verwysingsraamwerk waarbinne gesprek oor die waardestelsel van die land kan plaasvind. Die doel van die gesprek is om die normatiewe pad te vind waarin die onderwysbeleid en die strategie vir skole gestuur behoort te word. Die Minister en sy departement wil graag die volle toewyding (commitment) van alle persone wat by die onderwyssektor betrokke is, probeer verseker - en veral dié van die skole. Die Manifesto is 'n oproep aan almal om die gees van 'n demokratiese, nie-rassige en nie-seksistiese Suid-Afrika te omhels (Asmal, 2001a:ii). 


\section{Wie se waardes word verhelder?}

In alle onderwysstelsels word die vraag Wie se waardes geld in die onderwys? op die een of ander tydstip gestel. Hierdie relations of powervraag word hoofsaaklik in onderwyspolitieke verband gestel, en die antwoord is meestal: Die waardes onderskryf deur die polities dominante groep in die samelewing. Ook in die geval van die Suid-Afrikaanse onderwysopset is die antwoord: die waardes onderskryf deur diegene wat sedert 1994 die politieke hef in die hand het. Hierdie gevolgtrekking kan op twee maniere gestaaf word: enersyds deur te verwys na amptelike uitsprake en standpunte sedert 1994, en andersyds deur te verwys na die waardes soos pertinent uitgespel in die vermelde Manifesto.

Volgens die teorie van openbare liberale moraliteit (die "basic rules of liberal polity" - Marsden, 1997:33) is dit die plig van die staat om 'n openbare morele kode, bestaande uit fundamentele sosiale reëls en basiese menseregte (vgl. De Ruyter, 1994:26) neer te lê, 'n kode wat alle ander morele kodes en tradisies sal transendeer. Waardes soos die neutraliteit van die staat, die reg van individue om hulle eie sienings en waardes te bepaal, die reg op verdraagsaamheid en die vryheid van godsdiens vorm die kern van so 'n kode. Die openbare morele kode is toepaslik op alle burgers en dit moet deur die staat (die regering) opgelê word. Die verskillende elemente van die kode is na veronderstelling in sigself inhoudloos aangesien die kode hoofsaaklik prosedureel van aard is. Dit skryf met ander woorde nie 'n bepaalde morele inhoud voor nie, maar fasiliteer wel 'n veelvoud van morele gedagtes. Dit waarborg die vryheid om vir jouself te besluit wat om te dink, te glo en te doen. So 'n stelsel van liberale moraliteit is, met ander woorde, ' $n$ voorwaarde vir die bestaan van ' $n$ pluriforme samelewing aangesien dit vreedsame naasbestaan moontlik maak (Snik, 1994:16).

Volgens die sogenaamde kommunitariste (of homogeniste) (vgl. Snik, 1994:17 e.v.) moet alle leerders grootword in die konteks van 'n "amptelike" nasionale of openbare morele kode of waardesisteem. Die sogenaamde pluriformiste verskil ietwat hiervan: volgens hulle het hedendaagse samelewings te divers geraak om slegs een nasionale of openbare morele kode of sisteem te hê. Die staat moet dus so neutraal as moontlik probeer bly. Die gunstigste scenario is dat die openbare morele kode of waardesisteem slegs daardie kernwaardes sal bevat wat werklik deur alle burgers van die land gedeel sal kan word.

Al hierdie benaderings tot die openbare morele kode veronderstel die bestaan van ' $n$ openbare morele kode wat slegs daardie waardes en ander elemente insluit waaroor alle mense in 'n land na veronderstelling 
eens kan wees. Die vraag is of mense wat vanuit 'n reformatoriese denkraamwerk dink, ook daarmee eens behoort te wees.

Soos aangetoon, vind 'n mens die openbare morele kode vir SuidAfrikaners op twee plekke: in algemene uitsprake deur die huidige bewindhebbers en in hulle publikasies, en in die besonder in die gemelde Manifesto on Values, Education and Democracy (2001). Die kernwaardes opgeneem in die openbare morele kode is: gelykheid, billikheid en regverdigheid, demokrasie, menseregte, nie-seksisme, verdraagsaamheid, veeltaligheid, toerekenbaarheid en verantwoordelikheid, sosiale eer en geregtigheid, nasieskap, die welsyn van almal, eerbied vir die self en vir andere, vir die tradisie, die Grondwet en die nasionale simbole, samewerking met die oog op 'n gemeenskaplike toekoms, vriendskap, versoening, die heling van wonde uit die verlede, die verwydering van rassisme en diskriminasie.

As 'n mens hierdie waardestelsel van nader bekyk, merk jy dat dit nie so lewensbeskoulik neutraal is as wat dit voorgee om te wees nie (of veronderstel is om te wees nie). Die openbare morele kode bevorder nie slegs eerbied vir die fundamentele regte van die mens nie, maar ook die ideaal van nasiebou (nasionalisme) en 'n demokratiese ekonomie volgens kapitalistiese styl. Dit is byvoorbeeld een van die strategiese oogmerke van die Tirisanoprojek van die Onderwysdepartement om 'n skoolstelsel te ontwikkel wat doeltreffend funksioneer met die oog op die verwesenliking van die opvoedkundige en sosiale doelstelling van die land. Een van die uitkomstes is 'n jeug toegerus met die waardes en vaardighede om betrokke te kan raak by die breër gemeenskap en die wêreld van werk (Dept. van Onderwys, 2000-2004:14, 28).

Die nuwe kurrikulum is "aimed at shaping morals and values rather than knowledge" (Asmal, 2001b:21). "Waardes" verwys hier na die elemente van die openbare morele kode. Die Revised National Curriculum Statement (Dept. van Onderwys, 2002b) stel dat die bevordering van waardes nie vir slegs die persoonlike ontwikkeling van die leerders belangrik is nie, maar ook om te verseker dat 'n nasionale Suid-Afrikaanse identiteit opgebou word (vgl. die voorwoord tot die Grondwet van 1996; Republic of South Africa, 1996). Die leerder van die toekoms is iemand vervul met die waardes van, en wat sal optree in die belang van 'n samelewing gebaseer op eerbied vir demokrasie, gelykheid, menslike waardigheid, lewe en sosiale geregtigheid. Die fokus is op die ontwikkeling van die self-in-samelewing. Die Lewensoriëntering Leerarea se visie van individuele groei is derhalwe deel van 'n groter poging om 'n demokratiese samelewing, 'n produktiewe ekonomie en verbeterde lewenskwaliteit te bevorder. Die doel van hierdie Leerarea is om leerders te bemagtig om hulle talente aan te wend met die oog op die verwerkliking van hulle eie 
potensiaal terwyl hulle ook die waardes vervat in die Grondwet van die land uitleef. Hulle moet derhalwe leer om hulle eie grondwetlike regte en verantwoordelikhede uit te oefen, om eerbied te toon vir die regte van andere en om verdraagsaamheid te toon vir kulturele en religieuse diversiteit met die oog op die bou van 'n demokratiese samelewing (kyk Revised Curriculum Statement Policy; Dept. van Onderwys, 2002a; vgl. ook die National Curriculum Statement Grades 10-12 (Schools); Dept. van Onderwys, 2002c:11).

Met betrekking tot die ekonomie van die land, merk Pillay (2002) op dat die Regering ' $n$ groot verskeidenheid belange moet tevrede stel, insluitende dié van sy werkersklasbasis, die opkomende swart elite, die oorwegend wit groot besigheid en sy bondgenote, sowel as die globale beleggersgemeenskap. Soos ander sentrum-linkse partye, vind die ANC dit moeilik om die lokstem van die globale ekonomie te ignoreer, asook om die logika te ontwyk dat alle ekonomiese en sosiale beleid ondergeskik behoort te wees aan die behoefte om buitelandse beleggings te lok ten einde die ekonomie te versterk. Regerende sentrum-linkse partye bevind hulself dus dikwels in situasies waar hulle na "links" moet praat om hulle eie ondersteuningsbasis tevrede te hou, maar na "regs" optree om beleggers gelukkig te hou:

Consistent with our political traditions as a movement, with a clear understanding of the complex and historic tasks we face, we will work to strengthen our co-operation with the business community, both local and domestic (sic), and our other social partners, to rebuild our country and bring about the renaissance of Africa (Mbeki, Okt. 2002).

Die uiteindelike doel is die opbou van 'n moderne, mededingende markgebaseerde ekonomie (Mbeki, 2003; Du Plessis, 2002).

Die openbare waardestelsel van ons land is dus duidelik nie sonder besondere lewensbeskoulike inhoud in sigself nie. Dit bestaan uit waardes wat verband hou met ideale aangaande die erkenning van fundamentele menseregte, sosiale transformasie, nasiebou, globalisme en die bevordering van hoogs tegnologiese, sosiaal-demokratiese kapitalisme (hoewel naakte, dit is neo-liberale, kapitalisme en ultra-linkse sosialisme verwerp word [vgl. Munusamy, 2002] is dit nogtans ' $\mathrm{n}$ vorm van "secularized capitalism" (Colson, 2001:170)). Die amptelike lewensvisie van die maghebbers is dus nie neutraal nie; dit is in sigself die uitdrukking van 'n "geloof" in bepaalde waardes en ideale (Medema, 1997:91).

Die geloof in hierdie waardes kom ook sterk na vore in die opsomming wat prof. Wilmot James geskryf het van die Manifesto on Values, Education and Democracy. Hy verwys byvoorbeeld na demokrasie, 
sosiale geregtigheid en billikheid, gelykheid, nie-rassisme en nieseksisme, menslike waardigheid (ubuntu), 'n oop samelewing, toerekenbaarheid en aanspreeklikheid, die "rule of law", eerbied en versoening (James, 2001:iii-v).

Die vraag Wie se waardes? kan dus soos volg beantwoord word: die waardes opgeneem in die openbare morele kode, opgestel en onderskryf deur die heersende onderwysbewindhebbers, in die veronderstelling dat alle Suid-Afrikaners hierdie waardes met mekaar (sal/kan/behoort te) deel.

\section{Verhelder of afgedwing?}

Volgens die Minister (in die televisie-onderhoud van 6 Mei 2003) skryf die huidige kurrikulums (vir Algemene sowel as die Voortgesette Onderwys en Opleiding) nie die inhoud van die waardes voor nie, dog wel die uitkomstes wat deur die leerders bereik moet word. Volgens hom is dit tipies van waardeverhelderende onderwys dat die nadruk nie geplaas word op die inhoude wat bereik moet word nie, maar wel op die prosesse van waardeverheldering (vgl. De Klerk, 2000:343-346). Die doel is dus klaarblyklik die verfyning van die reeds bestaande openbare morele kode, en die verheldering van die waardes daarin opgesluit (Asmal, 2003).

Nou is dit egter opvallend dat sowel die Minister as prof. James in hulle toeligting op die waardes opgeneem in die vermelde Manifesto twee soorte woordeskat gebruik om die proses te beskryf. Enersyds word woorde gebruik wat inderdaad dui op blote verheldering van waardes. Asmal (2001a:ii) verwys byvoorbeeld daarna dat die debat oor waardes eintlik nooit tot 'n einde sal kom nie. James (2001:iii) meld dat die leerders aangemoedig moet word om tot 'n gemeenskaplike toewyding aan waardes te kom. Hy skryf onder meer: "There is no intention to impose values, but to generate discussion and debate, and to acknowledge that discussion and debate are values in themselves".

Teenoor hierdie gedagte van die verheldering van waardes gebruik sowel die Minister as James woordeskat wat daarop dui dat die waardes opgeneem in die openbare morele kode so belangrik is vir die huidige bewindhebbers dat hulle in werklikheid by die leerders tuisgebring moet word. Woorde en uitdrukkings soos die volgende word in hierdie verband gebruik: visie vir die mense van die land; saamsnoerende strome van demokrasie en nasiebou; die fokus van ons gedagtes op die normatiewe rigting van onderwysbeleid en strategie in ons skole, die soeke na die volledige toewyding van alle individue betrokke by die onderwyssektor, en die skole in die besonder; 'n oproep aan almal om die gees van 'n 
demokratiese, nie-rassige en nie-seksistiese Suid-Afrika te omhels (Asmal, 2001a:i-ii). James (2001:iii-iv) gebruik nog sterker woorde om te toon dat (en hoedat) die waardes daadwerklik by die leerders tuisgebring moet word:

[S]ix qualities of the education system should actively promote; (values as) ideals and concepts; brought to life in the classroom, as well as applied practically in programmes and policy making by educators, administrators, governing bodies and officials; instilling democratic values; encourage to develop a shared commitment to (the values); (values as) the common currency that makes life meaningful, and the normative principles that ensure ease of life lived in common; inculcating a sense of values at school; instilling in pupils and students a broad sense of values; The approach of the Manifesto is founded on the idea that the Constitution expresses South Africans' shared aspirations, and the moral and ethical direction they have set for the future (kursivering - JLvdW).

\section{Wanneer eindig die waardeverhelderingsdebat?}

Hoewel waardeverheldering 'n proses is, en daar nie eintlik op die inhoud daarvan gekonsentreer word nie, moet alle prosesse ' $n$ doel hê. Die doel in hierdie geval is waardeverheldering. Die vraag wat nou ontstaan, is: wanneer is die doel bereik? Volgens die Minister van Onderwys kan die proses van waardeverheldering nooit afgehandel wees nie:

Because (the Manifesto) is a document that operates in the realm of values, ideas and philosophy, the debate will never really be closed or end, and indeed ought to remain alive at this time and in the future (Asmal, 2001a:ii).

\section{Evaluering vanuit ' $n$ reformatoriese denkraamwerk}

\subsection{Die sekulêre aard van die openbare morele kode}

Hoewel daar nie vanuit 'n reformatoriese denkraamwerk ernstige kritiek op die waardes opgeneem in die openbare morele kode van die owerhede uitgespreek kan word nie (die meeste van hulle het tewens hulle oorsprong in die Christelike erfenis, vgl. Jeffrey, 1997:42-43), en hoewel die noodsaaklikheid van sodanige openbare waardestelsel in 'n land (vir 'n nasie) erken word, moet gekonstateer word dat hierdie waardestelsel nie inhoudelik meer voldoen aan die eise van die reformatoriese lewensvisie nie. Hoewel baie van die waardes wel hulle oorsprong in die Christelike erfenis gehad het, is hulle sedertdien inhoudelik so verskraal, "leeggemaak" en "uitgehol" dat hulle tans in 'n openbare morele kode ingesluit kan word om ook ander, selfs nieChristelike waardesisteme, te kan omvat en akkommodeer. 
'n Mens besef dat dit nie haalbaar is om in die huidige samelewings- en skole-opset in Suid-Afrika aan te dring op 'n fundamenteel Christelike of Bybelse benadering tot alle onderwyssake nie, maar dit bly betreurenswaardig dat die huidige morele kode enersyds poog om so neutraal as moontlik te wees (die bekende pragmatistiese korridor-benadering), en andersyds dat dit so volslae sekulêr is - gerig op die land en sy mense. Pertinent gestel: in die huidige openbare morele kode merk 'n mens niks van God as die Skepper en Onderhouer van alle dinge, van die mens as die beeld en dus rentmeester van God, as 'n gevalle en herstelde wese in Jesus Christus, van die transformasie van die skepping, en dus die hedendaagse kulturele lewe, op grond van die soenverdienste van Christus, en dies meer nie. Die openbare morele kode is dus inderdaad sekulêr (nie op God gerig; wêrelds; "horisontalisties-mensgerig") in skering en inslag.

\subsection{Bevoordeling en bevoorregting van die openbare morele kode}

Waardeverheldering in onderwyskonteks is noodsaaklik - dog in die veronderstelling dat ook die waardes van 'n reformatoriese, Christelike, Bybelse lewensopvatting (benewens ander lewensopvattings) aan die orde gestel sal word. Alles dui egter daarop (vgl. die debat oor godsdiensonderwys en godsdienstige plegtighede in skole, Mei-Julie 2003) dat slegs die waardes opgesluit in die openbare morele kode in die waardeverhelderingsdebat toegelaat word, en dat enige ander waardes en waardesisteme de facto na die situasie buite die skool(kurrikulum) verban is. Kommerwekkend is die feit dat daar oënskynlik van die veronderstelling uitgegaan word dat die openbare morele kode die enigste waardesisteem is wat aktief en doelgerig in die skoolonderwys by die leerders tuisgebring behoort te word, terwyl alle ander waardesisteme uitgeban word tot die domein van die leerders se ouerhuise, kerke, persoonlike en private lewens (Jeffrey, 1997:30, 38).

Die reformatoriese lewensbeskouing vorm egter 'n konseptuele struktuur aan die hand waarvan ons kan bepaal wat verkeerd is met, en onaanvaarbaar is in ander waardestelsels, en om eie perspektiewe op sake te formuleer (Colson, 2001:19). Om hierdie rede weier die Christen dat sy geloof en lewensbeskoulike oortuigings tot die domein van die privaatheid van die kerk of die ouerhuis teruggedwing word; dit moet deel vorm en bly van die openbare waardeverhelderingsproses, ook in skole, aangesien dit die manier is waarop die Christelike geloof ' $n$ kreatiewe mag in ons samelewing kan wees en bly (Colson, 2001:30). Ooreenkomstig die sentraal-teoretiese uitgangspunt waarop hierdie betoog gebou is (kyk 1 hierbo), behoort die proses van waardeverheldering in Suid-Afrikaanse skole só ingerig te word dat die leerders in die formele 
skoolsituasie (kurrikulum sowel as onderrig-leersituasie) die geleentheid kry om verheldering van hulle eie waardesisteme, insluitend dié van die betrokke godsdienstige gemeenskap waaraan hulle onderskeidelik behoort, te kan doen.

\subsection{Die gewaande objektiwiteit van die openbare morele kode}

Die veronderstelling skyn ook te wees dat die openbare morele kode die enigste is wat die status van objektiwiteit verdien, terwyl alle ander op die agtergrond geskuif moet word omdat hulle subjektief van aard sou wees, en derhalwe nie deur alle Suid-Afrikaners gedeel kan word nie. Soos aangetoon, is ook die waardes opgeneem in die openbare morele kode met subjektiewe sekulêre inhoud gevul.

\subsection{Die beperktheid van die waardeverhelderingsproses}

Die huidige proses van waardeverheldering het bloot ten doel om die waardes wat die politieke maghebbers onderskryf, te verhelder. Die verhelderingsproses skyn twee eienskappe te hê:

- enersyds moet die proses eintlik nooit as afgehandel beskou word nie, wat impliseer dat die leerders in die skole voortdurend met die betekenis en implikasies van die openbare morele kode moet worstel; en

- uit die woordeskat wat in verband met die verhelderingsproses gebruik word, is dit duidelik dat die leerders met hierdie waardes toegerus en selfs geïndoktrineer moet word. Hulle moet, onder meer deur besinning en verheldering van die waardes in die openbare morele kode, die waardes hulle eie maak, en sodoende bydra tot die nasionale doelstellings van nasiebou, nasietrots en demokrasie.

Vanuit 'n reformatoriese besinning oor die rol van beginsels, norme en waardes in die onderwys is so 'n benadering tot die verhelderings- en internaliseringsproses nie bevredigend nie. 'n Bybelsgefundeerde lewensbeskouing is gegrond op vaste "waardes" (die beginsels van skepping, sondeval, verlossing, herstel). Hoewel hierdie "waardes" (beginsels) vas is, moet hulle ook verhelder word, en sodanige verheldering moet geskied deur opvoedende onderrig tot op die punt dat die leerder die waardes verstaan en hulle eie maak, of hulle verwerp. Verheldering is dus vanuit reformatoriese standpunt nie 'n ewigdurende proses wat om sigself geskied nie, of wat slegs sekulêre waardes verhelder nie. Dit behoort waardes te verhelder wat, in die geval van die reformatoriese opvoeder en opvoedeling, voortvloei uit 'n Bybelse lewensbeskouing, en die verheldering geskied slegs tot op daardie punt dat die waardes geïnternaliseer (verinwendig) is en werklik lewensbeskoulike rigting aan 
die lewe van die betrokke persoon kan gee. Leerders moet dus nie geïndoktrineer word met 'n waardestelsel nie; hulle moet altyd die keuse hê om waardes te aanvaar (internaliseer) of te verwerp.

\subsection{Filosofiese wortels van die waardeverhelderingsproses}

Waardeverheldering as proses is filosofies gefundeer in verskeie werklikheidsvisies, waaronder die Darwinisme/naturalisme (organismes groei deur aanpassing by die omgewing), die pragmatisme (daar is geen transendente, onveranderlike waarhede nie) en empirisme (feite en waarhede word slegs deur ervaring geken en bemeester) (vgl. De Klerk, 2000:343 e.v.). Hierdie gedagte word ook deur die konstruktivisme bevorder (vgl. Kukla, 2000 vir 'n volledige bespreking van hierdie benadering). Waardes is volgens laasgenoemde benadering nie objektief nie, maar wel 'n sosiale konstruksie van die leerder. Leerders moet dus nie die "regte" antwoorde van die opvoeder ontvang nie, maar moet gehelp word om hulle eie oplossings te konstrueer deur interaksies met die opvoeder en die groep. Die leerder word nie meer gekonfronteer met die teenwoordigheid van 'n objektiewe realiteit buite die self nie, maar daar word van hom of haar verwag om 'n eie realiteit te konstrueer (in hierdie geval self inhoud te gee aan die waardes). In die proses transformeer die leerder dan die self sowel as die realiteit. Die leerders moet ook nie van die opvoeder hoor of hulle reg of verkeerd dink nie. Die probleem met hierdie benadering is egter die volgende:

If ethical norms are socially constructed, and if all criteria by which we would judge the legitimacy of social constructions are themselves embedded in other social constructions, then we find ourselves in a situation where it is impossible to come to any final ethical decisions. ... Recognizing that there is no moral order apart from the moral order that we impose on our own socially constructed world leaves us submerged in anomic horror (Middleton \& Walsh, 1995:60-61).

In die waardeverhelderingsproses word die konstruktivistiese leerteorie dus kennelik toegepas op die terrein van waardes, etiek en moraliteit. Deur ' $n$ proses van verheldering kom 'n mens na veronderstelling tot sekere waardes wat waarskynlik vir almal die beste sal wees en tot aangename konsekwensies kan lei (Colson, 2001:80). Omdat die waardes steeds "kontingent geld" ('n waarde vir my is nie noodwendig 'n waarde vir jou nie) het 'n mens hier te doen met 'n vorm van relativistiese morele opvoeding. In alle vorme van waardeverhelderende onderwys probeer die onderwyser so ver as moontlik om nie voorskriftelik te wees nie, maar om die leerders te lei om verskillende moontlikhede teen mekaar op te weeg en dan self te besluit. 
Vanuit 'n reformatoriese denkraamwerk kan 'n mens verskeie besware teen hierdie beskouing opper: God het die werklikheid geskep as iets objektiefs buite die mens - iets wat dus deur middel van die sintuie geken kan word. Die gedagte dat elke mens 'n eie werklikheid skep, is nie aanvaarbaar nie, aangesien ons dan met 'n relativistiese werklikheidsbeskouing te make het. Voorts is dit juis een van die kenmerke van opvoeding dat die opvoeder, synde die meer volwasse en beter toegeruste persoon in die opvoedingsverhouding, rigting en leiding aan die opvoedeling moet verskaf. Wanneer onvolwasse persone nie toegerus word met kennis van wat goed en kwaad, reg en verkeerd is nie, verval hulle in allerlei relativistiese sieninge. Die reformatoriese lewensbeskouing verskaf aan die Christenopvoeder ' $n$ transendente standaard waaraan sieninge, beskouinge en standaarde behoort te beantwoord. Colson (2001:82-4) vat die kernbeswaar teen waardeverhelderende onderwys soos volg saam:

Today ... utopianism (d.i. 'n optimistiese kindbeskouing) is at work in nondirective values-education programs, which ... are based on the assumption that if children are merely taught a process of inquiry to evaluate their options, they will choose wisely and rationally... No wonder research shows that students who take 'life-style' courses employing nondirective decision-making methods end up being more likely to engage in destructive behavior.'

\subsection{Die kloof tussen die veronderstelde private en openbare dele van die menslike bestaan}

Die huidige vorm van waardeverheldering dui op 'n relativistiese etiek, dit wil sê een waarin elke individu self 'n stel private waardes en waarhede moet uitkerf en daarvolgens leef (Jeffrey, 1997:30). Waardeverheldering in sy huidige gestalte skep 'n kloof tussen wat as openbaar en wat as privaat beskou word. Die noodwendige gevolg hiervan is dat leerders grootword as gesplete, gefragmenteerde en gekompartementaliseerde mense. Volgens die Bybelse beskouing van die mens is dit nie aanvaarbaar dat iemand kan aanvoer: "Dit maak nie saak wat die President van die land in sy private lewe doen nie" of: "Wat ek in my private lewe doen, skeel niemand nie". Hierdie soort stellings dui op 'n dualistiese mensbeskouing, wat strydig is met die Bybelse siening van die menslike aard. Volgens die Christelike beskouing van die mens loop die integriteit van die mens (mens as eenheid, geheel) regdeur al sy/haar handelinge, hoe klein of groot ook al, sowel in die openbare as in die private lewe. Die mens is één, een en dieselfde persoon, ongeag wat hy doen of waar hy hom bevind (vgl. Marsden, 1997:20). 


\subsection{Die openbare morele kode se gebrek aan religieuse wortels en identiteit}

Die nadruk op "waardes", veral sedert die Tweede Wêreldoorlog, neig om by te dra tot ' $n$ verlies aan religieuse identiteit. Niemand kan teen waardes wees nie; almal - ook die skole - behoort waardes na te streef. Dit is egter juis die probleem met "waardes", meen Marsden (1997:104105). Almal kan sekere waardes aanhang omdat hulle geen duidelike betekenis of inhoud het nie. Eers wanneer waardes gefundeer word in 'n eie religieuse oortuigingsraamwerk kan hulle werklik inhoud kry, en gebruik word as gronde vir morele oordeel. Juis op hierdie gronde is dit van belang dat die eie waardestelsel van die leerder - in die formele skoolkonteks - verhelder behoort te word. Die fundering van die betrokke waardes in die eie godsdiens en lewensvisie bring die waardes eers werklik tot lewe en gee aan hulle inhoud. In hierdie proses kan leerders ook beter begrip vir mekaar se waardes kry, en dus leer om meer verdraagsaam teenoor mekaar te wees.

\subsection{Diverse ander kritiekpunte op die waardeverhelderingsproses}

Voortvloeiend uit voorgaande kritiekpunte kan ook die volgende besware teen die huidige proses van waardeverheldering geopper word:

- Dit is misleidend om te praat van waardeverheldering, terwyl die bedoeling is dat slegs die waardes wat die onderwysowerhede onderskryf, verhelder word. Die kernprobleem met hierdie manier van doen is dat dit reduksionisties van aard is: die waardes wat leerders behoort te huldig word gereduseer tot slegs dit wat volgens politieke maghebbers algemeen aanvaarbaar is of behoort te wees (Marsden, 1997:75).

- Dit is onaanvaarbaar dat slegs die waardes opgeneem in 'n sekulêre openbare morele kode verhelder word. As 'n mens dit doen, maak jy jou skuldig aan 'n ander dualisme, naamlik 'n onderskeid/skeiding tussen dit wat as sekulêr en dit was as "heilig" (sakraal) beskou word (Marsden, 1997:21). Vanuit reformatoriese denkraamwerk bestaan daar geen sodanige dualisme nie. Geen duimbreedte van die menslike bestaan (ook nie in skoolverband) kan onttrek word aan die soewereine heerskappy van God nie.

- Die kernprobleem met 'n "neutrale" en/of "sekulêre" openbare morele kode is dat die waardes wat daarin opgeneem is na veronderstelling vir almal moet geld, maar in werklikheid deur niemand toegeëien kan word nie. Slegs wanneer waardes vanuit die eie lewensopvatting met inhoud gevul is, kan hulle waarlik deur 'n bepaalde persoon eie gemaak word. 
- Waardeverhelderende onderwys stel inhoud teenoor proses. Geen proses is ooit inhoud- of waardevry nie. Dit is met ander woorde oneerlik om te beweer dat waardeverheldering slegs ' $n$ proses is; in die proses word leerders onvermydelik geïndoktrineer met die waardes opgeneem in die openbare morele kode.

- Waardeverhelderende onderwys soos dit tans gekonseptualiseer is, speel die objektiewe teenoor die subjektiewe af. Die openbare morele kode word beskou as objektief-geldend vir alle mense, terwyl die waardes voortvloeiend uit die eie godsdiens of lewensbeskouing as subjektief en persoonlik beskou word.

- Die dualismes kenmerkend van waardeverhelderende onderwys (openbaar/privaat; sekulêr/sakraal; proses/inhoud; objektief/subjektief) lei onvermydelik tot 'n kloof tussen die skool aan die een kant (waar die openbare waardesisteem verhelder word) en die ouerhuis en kerk, aan die ander kant (waar die private en persoonlike waardes verhelder kan word en kan geld).

- Voortvloeiend hieruit ontstaan die wanopvatting aan die kant van die onderwysowerhede dat die skool aan die staat behoort, en dat die staat dus die waardesisteem van die skool kan bepaal en voorskryf. Dit is egter nie die geval nie; die skool behoort in eerste instansie aan die ouers, die leerders en die onderwysers. Die staat befonds slegs die skool namens hierdie partye met belastingbetalersgeld. Dit gee nie aan die staat die reg om oor die waardesisteem te besluit wat in 'n skool behoort te geld nie.

- Waardeverhelderende onderwys misken nie slegs die integrale aard van die mens nie, maar ook van die lewensbeskouing. Die oortuigings voortvloeiend uit laasgenoemde geld op elke denkbare terrein van 'n mens se lewe.

\section{Slotsom: die waarde van waardeverhelderende onderwys}

Waardeverhelderende onderwys soos dit tans daar uitsien in die SuidAfrikaanse openbare skole-opset het, vanuit reformatoriese oogpunt beoordeel, slegs beperkte waarde. Dit stel Christen-leerders wel in staat om te verstaan watter waardes alle Suid-Afrikaners met mekaar in gemeen het, of veronderstel is om met mekaar te deel. Hoewel die verskillende waardes opgeneem in die openbare morele kode wel teruggevind kan word in die Woord van God, bly dit problematies vir sowel die Christen-onderwyser as -ouer en -kind dat hulle nie die geleentheid kry om sodanige fundering in skoolverband te doen nie. In weerwil van die argument dat die onderrig in en die beoefening van die verskillende spesifieke godsdienste binne normale skoolure en as deel van die formele kurikulum verdelend sal werk in die Suid-Afrikaanse 
samelewing, moet gestel word dat dit noodsaaklik is dat hierdie fasette van opvoedende onderwys wel toegelaat behoort te word. Sulke bydraes vanuit die verskillende spesifieke (eie) godsdienstige denkraamwerke is die enigste wat kan bydra tot ware waardeverheldering, en dus tot ware opvoedende onderwys.

Soos sake tans staan, kom waardeverhelderende onderwys slegs neer op die verheldering van die gewaande "neutrale" dog sekulêre waardes onderskryf deur die huidige politieke maghebbers.

\section{Bibliografie}

ASMAL, K. 2001a. Foreword. Ministerie van Onderwys. Manifesto on Values, Education and Democracy. Augustus.

ASMAL, K. 2001b. All our children deserve the best education. Sunday Times, Jul. 29.

ASMAL, K. 2003. Onderhoud met die Minister. SABC-TV2, Mei 6.

COLLINS CONCISE DICTIONARY. 1999. Glasgow : Harper Collins.

COLSON, C. 2001. The Christian in today's culture. Wheaton : Tyndale House.

DE RUYTER, D. 1994. Op weg naar een nieuwe staatspedagogiek? (In Miedema, S. \& Klifman, H. Christelijk onderwijs in ontwikkeling. Kampen : Kok. p. 23-29.)

DE KLERK, J. 2000. Waarde-uitklaring: Trojaanse perd in Suid-Afrikaanse skole? Koers, 65(3):341-356.

DEPARTEMENT VAN ONDERWYS. 2000-2004. Implementation plan for Tirisano. Working together to build an education and training plan for South Africa. Pretoria : Department of Education.

DEPARTEMENT VAN ONDERWYS. 2002a. Life Orientation. Revised National Curriculum Statement Grades R-9 (Schools) Policy. Pretoria : Department of Education.

DEPARTEMENT VAN ONDERWYS. 2002b. Overview. National Curriculum Statement Grades 10-12 (Schools). Oct. 28.

DEPARTEMENT VAN ONDERWYS. 2002c. Natural Sciences. Revised National Curriculum Statement Grades R-9 (Schools) Policy. Pretoria : Department of Education.

DU PLESSIS, T. 2002. Seine aan die land uit Stellenbosch. Rapport, Desember 22.

HUMALDA, D. 1995. De waardendiscussie als (op)gave. (In Miedema, S. \& Vijver, H.W., reds. Visie als venster. Kampen : Kok. p. 60-74.)

JAMES, W. 2001. Executive summary. Ministerie van Onderwys. Manifesto on Values, Education and Democracy. Aug.

JEFFREY, G.R. 1997. The handwriting of God: Sacred mysteries of the Bible. Wheaton: Tyndale House.

KUKLA, A. 2000. Social constructivism and the philosophy of science. London : Routledge.

MANIFESTO ON VALUES, EDUCATION AND DEMOCRACY. 2001 kyk: Ministerie van Onderwys.

MARSDEN, G.M. 1997. The outrageous idea of Christian scholarship. New York : Oxford University Press.

MBEKI, T. 2002. Internet. ANC Today, Oct.

MBEKI, T. 2003. State of the Nation Address. Parlement: Republic of South Africa.

MEDEMA, H. 1997. Water, wijn en waarheid. Vaassen : Medema. 
MIDDLETON, J.R. \& WALSH, B.J. 1995. Truth is stranger than it used to be. Downers Grove : InterVarsity.

MINISTERIE VAN ONDERWYS. 2001. Manifesto on Values, Education and Democracy. Aug.

MUNUSAMY, R. 2002. Wake up - and smell the roses. Business Times, Oct. 20.

PILLAY, D. 2002. Between the market and a hard place. Sunday Times, Oct. 6.

REPUBLIC OF SOUTH AFRICA. 1996. Grondwet van die Republiek van Suid-Afrika (Wet 108 van 1996).

SNIK, G. 1994. Waardenoverdracht en vrijheid van onderwijs. (In Miedema, S. \& Klifman, H. Christelijk onderwijs in ontwikkeling. Kampen : Kok. p. 12-22.)

TENNEKES, J. 1992. Christenen en cultuurvorming. (In De Knijff, H.W., Dekker, G. \& Tennekes, J. Christelijke waarden in een geseculariseerde cultuur. Amsterdam : VU Uitgeverij. p.35-62.)

\section{Kernbegrippe:}

openbare morele kode reformatoriese perspektief waardestelsels waardeverheldering; binne die Suid-Afrikaanse onderwysstelsel

\section{Key concepts:}

public moral code reformational perspective value systems values clarification; within the South African educational system 